\title{
Role of B Lymphocytes in New Bone Formation
}

\author{
Ana Marusic, Danka Grcevic, Vedran Katavic, Natasa Kovacic, Ivan Kresimir Lukic, \\ Ivo Kalajzic, and Joseph A. Lorenzo
}

Croatian Institute for Brain Research and Department of Anatomy (AM, VK, NK, IKL) and Department of Physiology and Immunology (DG), Zagreb University School of Medicine, Zagreb, Croatia; and Department of Genetics and Developmental Biology (IK) and Division of Endocrinology and Metabolism (JAL), Department of Medicine, University of Connecticut Health Center, Farmington, Connecticut

SUMMARY: Although there may be a close relationship between B lymphocytes and osteoclasts, or bone resorbing cells, little is known about the role of $B$ lymphocytes in bone formation. We compared in vivo new bone induction in mice homozygous for the B-cell deficient ( $\mu \mathrm{MT})$ gene knockout, which lack functional B lymphocytes, with bone induction in control wild-type (C57BL/6) mice. Our comparison used two models of new bone induction in vivo: endochondral osteoinduction by subcutaneous implantation of recombinant human bone morphogenetic protein (rhBMP-2) and osteogenic regeneration after tibial bone marrow ablation. The expression of bone-specific proteins (bone sialoprotein, osteopontin, and osteocalcin) and inflammatory/ immunomodulatory cytokines (interleukin- $1 \alpha$ and $-1 \beta$, interleukin-6, and tumor necrosis factor- $\alpha$ ) was assessed by Northern blot analysis or reverse transcription-polymerase chain reaction, respectively. Ossicles induced by rhBMP-2 were larger in volume and mass in $\mu \mathrm{MT}$ knockout mice, but relative volumes of the newly induced bone, cartilage, and bone marrow were similar in the two groups. Six days after tibial bone marrow ablation, $\mu \mathrm{MT}$ knockout mice resorbed the initial blood clot faster and formed more trabecular bone, paralleled by greater levels of bone sialoprotein mRNA than in the wild-type mice. $\mu$ MT knockout and wild-type mice also differed in the expression pattern of inflammatory/immunomodulatory cytokines during the development of the newly induced bone, suggesting that a genetic lack of B lymphocytes may create a change in the immunological milieu at the site of new bone induction, which stimulates the initial accumulation and proliferation of mesenchymal progenitor. (Lab Invest 2000, 80 : 1761-1774).

\begin{abstract}
$I$ nteractions between the bone and the immune/ hematopoietic system occur for both anatomical and functional reasons. Osteoclasts, the bone resorbing cells, develop from precursors residing in the hematopoietic marrow (Rifas, 1999), and osteoblasts, the bone forming cells, can differentiate from the marrow stroma (Encina et al, 1999) that is, in turn, a requirement for normal hematopoiesis (Dexter et al, 1977). Many agents produced by or acting on immune/hematopoietic cells have powerful effects on bone, and vice versa (Rifas, 1999; Sharrock 1998). However, much of the in vivo data on bone turnover in immunodeficient animals are contradictory. Marked decreases in bone formation and resorption have been reported in athymic mice, which lack T lymphocytes (Vignery et al, 1981), although other studies in athymic mice (McCauley et al, 1989) or rats (Buchinsky et al, 1995) found that the physiological bone turnover in those animals is comparable to that of euthymic controls. Our laboratory has shown that
\end{abstract}

Received August 16, 2000.

This work was supported by grants from the Ministry of Science and Technology of the Republic of Croatia, No. 108148 and 1080110, and by US-Croatian Joint Research Grant No. JF198. Abstract presented at the Bone Morphogenetic Proteins: First European Conference, Zagreb, Croatia, October 7-11, 1998.

Address reprint requests to: Dr. Ana Marusic, Croatian Institute for Brain Research, Zagreb University School of Medicine, Salata 3, HR-10000 Zagreb, Croatia.Fax: 3851459 0222; E-mail:marusica@mef.hr thymectomized rats, which have a depression of cellular immunity, have higher rates of new bone induction by demineralized bone matrix than control rats (Marusic et al, 1992). In contrast, mice with a gene knockout for $\beta 2$-microglobulin, which lack functional major histocompatibility complex (MHC) class I molecules and have impaired cellular immune response, have physiological bone turnover similar to that of heterozygous litter mates (Marusic et al, 1995).

It has recently been shown that B lymphocytes may be an important regulator of both normal and pathological bone resorption. Estrogen, a powerful regulator of bone mass, is involved in the differentiation of the B-cell hematopoietic lineage (Smitson et al, 1995) and increased B-lymphopoiesis may be involved in the mechanism of stimulated bone resorption that is seen with estrogen deficiency (Masuzawa et al, 1994). Mice with a gene knockout for nuclear transcription factor $x \mathrm{~B}(\mathrm{NF}-x \mathrm{~B})$, whose activation is involved in the survival of osteoclasts (Jimi et al, 1998), fail to generate both B lymphocytes and mature osteoclasts (Franzoso et al, 1997). Mice transgenic for human T-cell lymphotropic virus type I, associated with T-cell leukemia, myelopathy, and arthropathy, have increased numbers of progenitor cells for both osteoclasts and B lymphocytes (Yamazaki et al, 1998). Interleukin-7 (IL-7) receptor knockout mice, which lack B-cells because of an arrest of B-lymphopoiesis at the pro-B-cell maturation stage, have increased trabecular bone volume (Miyaura et al, 1997). Although concurrent changes in 
osteoclastogenesis and B-lymphopoiesis described in these reports may be unrelated, a recent report on the regulation of commitment to the $\mathrm{B}$-lymphoid lineage provided direct evidence that B-lymphocyte precursor cells can differentiate into osteoclasts in vitro and in vivo (Nutt et al, 1999).

In contrast to the growing experimental support for the close relationship between $B$ lymphocytes and osteoclasts, the role of B lymphocytes in the proliferation and differentiation of osteoblasts has not been investigated. Based on the evidence that the differentiation of osteoclasts is regulated by factors produced or transduced by osteoblasts/stromal cells (Yasuda et al, 1998), we hypothesized that B lymphocytes should be involved not only in the differentiation of osteoclasts but also in the regulation of bone formation by osteoblasts. To this aim, we studied new bone formation in B-cell-deficient mice produced by targeted disruption of the $\mu$-chain ( $\mu \mathrm{MT}$ mutation), which arrests B-cell development at the preB-cell maturation stage (Kitamura et al, 1991). New bone formation was assessed using two well-defined in vivo models: ectopic bone induction by bone morphogenetic proteins (BMPs), which recapitulates cellular events in endochondral bone formation and bone regeneration after fracture repair (Urist, 1995); and bone regeneration after bone marrow injury as a model of synchronous bone formation in a well-defined anatomical location (Shimizu et al, 1998; Suva et al, 1993; Tanaka et al, 1996). We present evidence that mice lacking functional $B$ lymphocytes reacted to an osteoinductive stimulus by producing a greater volume of new bone, which was morphologically similar to the reaction of the wild-type controls. These changes were paralleled by changes in the expression pattern of bone-related markers and inflammatory/immunomodulatory cytokines.

\section{Results}

\section{Morphology of Newly Induced Bone in $\mu$ MT-/- Mice}

Because bone can develop by two differentiation patterns, we analyzed bone formation in vivo in two models: one involving osteogenesis via a cartilaginous scaffold and the other where osteoblasts differentiate directly from the mesenchymal precursors.

The cellular cascade of endochondral bone formation induced by recombinant human bone morphogenetic protein (rhBMP-2) in a blood clot as a carrier in the wild-type mice was similar to that described in other systems using recombinant BMPs or bone matrix gelatin (Marusic et al, 1996; Urist, 1995,): mesenchymal progenitor cell chemotaxis and proliferation was followed by cartilage differentiation and hypertrophy, angiogenesis and invasion of bone marrow cells, osteoblast differentiation, and final formation of new bone that was remodeled into an ossicle filled with hematopoietic marrow (data not shown). We chose two time points in this cellular cascade for histological analysis of newly formed tissues: at the beginning of the cellular proliferation and differentiation and when the ossicle is fully organized. The first time point was 7 days after rhBMP-2 implantation, when the blood clot as a source of rhBMP-2 was surrounded by a large mass of proliferating mesenchyme with very little newly induced cartilage or bone (Figs. 1 and 2, A and B). Relative volumes of the blood clot, mesenchyme, cartilage, bone, or bone marrow in implants were similar in wild-type and $\mu \mathrm{MT}-/-$ mice (Fig. 1). It is important to emphasize that the histomorphometric
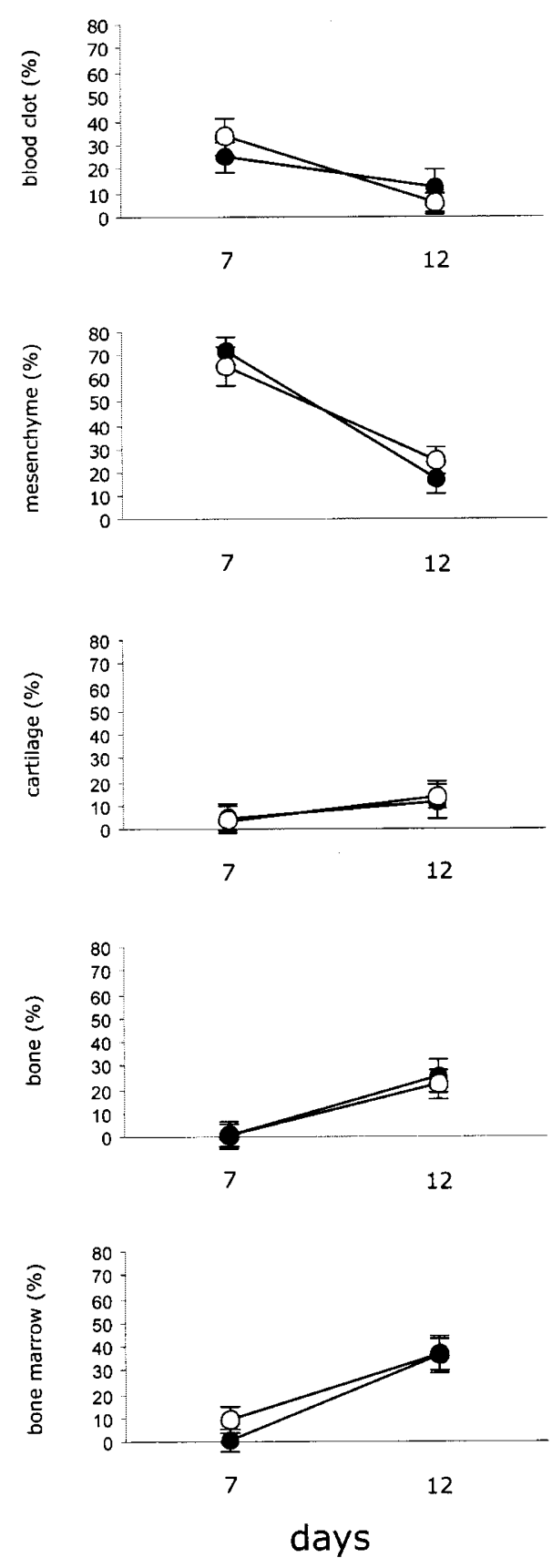

Figure 1.

Histomorphometry of new bone induced by subcutaneous implantation of $5 \mu \mathrm{g}$ recombinant human bone morphogenetic protein (rhBMP)-2 in $50 \mu \mathrm{l}$ coagulated blood as a carrier. The results are expressed as tissue volume/total implant volume (\%, mean $\pm \mathrm{sD})$. Histomorphometry was performed on serial sections of the implants (every 10th section throughout the whole implant thickness) from 4 to 5 mice per group at each time point. The implantation of blood clot without added rhBMP-2 did not induce new tissue. Open circles, wild-type (C57BL/6J) mice; closed circles, mice homozygous for the $\mu \mathrm{MT}$ gene knockout $(\mu \mathrm{MT}-/-)$. 
analysis was always performed on serial sections of the implants, allowing us to make conclusions about the whole ossicle. The volume (Fig. 2) and mass of the whole implants or newly induced tissue from $\mu \mathrm{MT}-/-$ mice were greater than those from the wild-type mice (Table 1). Five days later, at 12 days post-implantation, the blood clot underwent significant resorption, and the mesenchymal mass differentiated into a mixture of cartilage, bone, and newly formed marrow space (Figs. 1 and 2, C and D). Again, relative volumes of the cellular compartments were similar in the two groups, but the mass of the ossicle in $\mu \mathrm{MT}-/$-mice was still
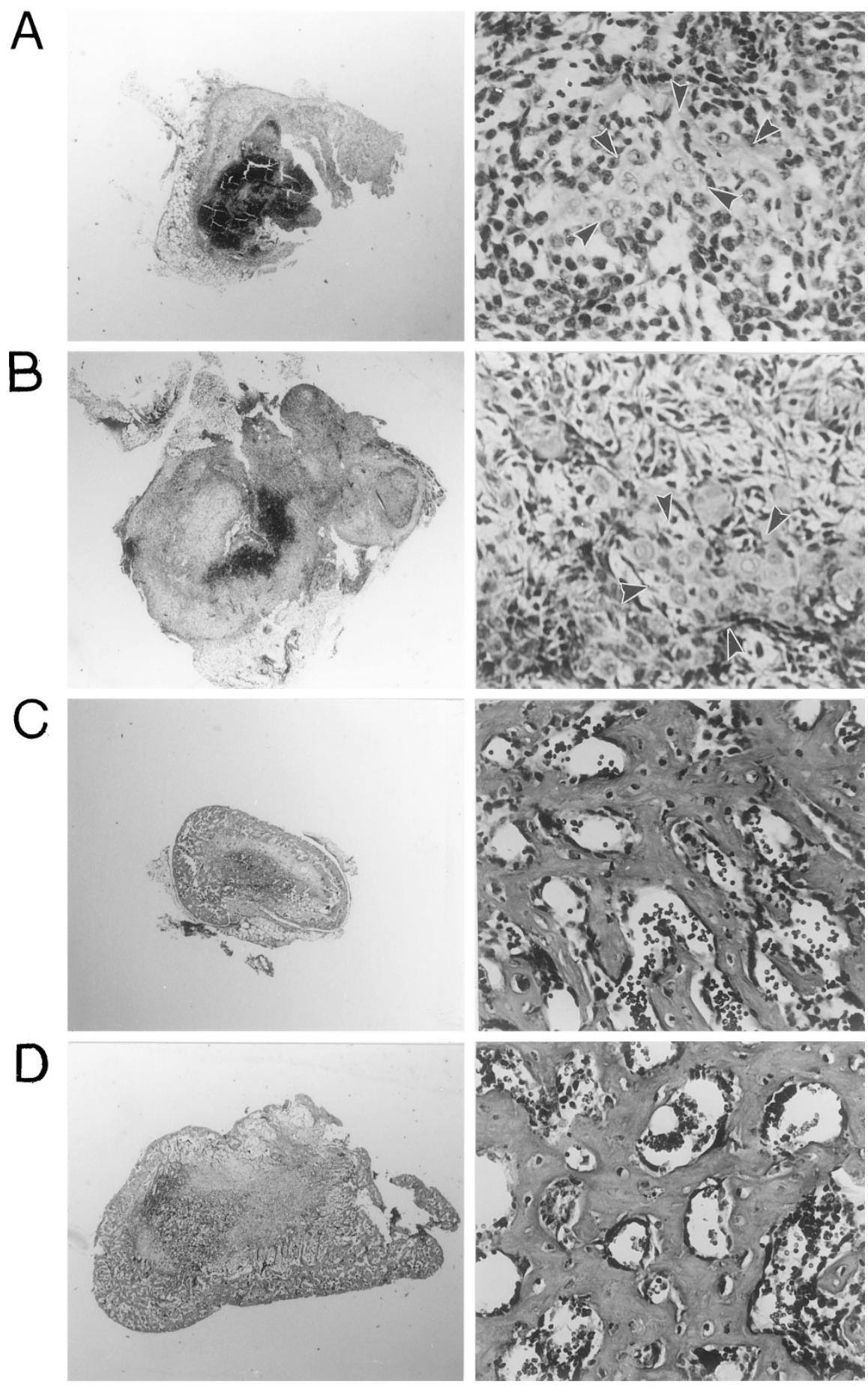

Figure 2.

Newly formed tissue after implantation of rhBMP-2 in $\mu \mathrm{MT}$-/- mice and the wild-type controls. Seven days after the implantation, the area of the largest cross-section of the ossicles from $\mu \mathrm{MT}-/-$ mice ( $A$, left panel) was greater than that from the wild-type controls ( $B$, left pane). At this time point, blood clot with rhBMP-2 in both groups ( $A$ and $B$, right panels) was surrounded by proliferating mesenchymal tissue and islands of differentiating cartilage (arrowheads). Twelve days after the implantation, the difference in size between the ossicles from $\mu \mathrm{MT}-/-(C$, left panel) and wild-type mice $(D$, right panel) was even more obvious. The blood clot underwent significant resorption and the mesenchyme differentiated into bone trabeculae and marrow space between them in both groups $(C$ and $D$, right panels). Original magnification, $\times 7.5$ (left panels) or $\times 200($ right panels) . 
2-fold greater than that from the wild-type controls (Table 1).

In the model of bone marrow injury, there is an orderly process of marrow regeneration after marrow ablation, which includes capillary invasion of the marrow cavity, the appearance of mesenchymal cells, osteoblast proliferation, cancellous bone formation, the reappearance of hematopoietic tissue and osteoclastic resorption, which leads to the final regeneration of normal marrow (Shimizu et al, 1998; Suva et al, 1993; Tanaka et al, 1996). In both wild-type and $\mu \mathrm{MT}-/-$ mice, the marrow cavity of the tibia was filled with a large blood clot immediately after marrow ablation (data not shown). Six days after marrow ablation, the blood clot filled about $40 \%$ of the marrow cavity in the wild-type mice, and a newly formed network of trabecular bone covered with active cuboidal osteoblasts occupied about $10 \%$ of the marrow cavity (Figs. 3 and 4). In $\mu \mathrm{MT}-/-$ mice, the initial blood clot occupied only $10 \%$ of the marrow cavity, and the newly forming bone occupied a significantly larger volume than in the wild-type controls (Fig. 3). The number of newly formed bone trabeculae was similar in both types of mice, but the trabeculae in $\mu \mathrm{MT}-/-$ mice were thicker and more densely packed (Fig. 3). Eight days after marrow ablation, the newly induced trabecular network increased in volume. This increase was greater in the wild-type mice, which equaled $\mu \mathrm{MT}-/-$ mice in all measured bone parameters at this time point (Fig. 3). However, the blood clot still occupied a larger volume in the wild-type mice than in $\mu \mathrm{MT}-/-$ mice (Fig. 3). At this time point, marrow sinuses and cellular marrow regeneration were evident in both groups, especially in the proximal diaphysis (data not shown). Ten days after marrow ablation, the blood clot was completely resorbed, and the diaphyseal cavity was filled with cancellous bone in both groups of mice (Figs. 3 and 4). The differentiation of the hematopoietic marrow continued and osteoclastic activity increased, as evidenced by tartrate-resistant acid phosphatase (TRAP) histochemistry (data not shown). At this time point, wild-type and $\mu \mathrm{MT}-/-$ mice had similar volumes of the cancellous bone, but the trabeculae in $\mu \mathrm{MT}-/-$ mice were more numerous (Fig. 3).

\section{Expression of Bone-Related Genes in Newly Formed Bone in $\mu M T-/-$ Mice}

The expression of three bone-related marker genesbone sialoprotein (BSP), osteopontin (OPN), and osteocalcin (OC) - was assessed by Northern blot analysis in both models of new bone formation. For the rhBMP-2 implants, RNA was isolated 7 and 12 days after implantation. Isolation of RNA from the implant at an earlier time point (3 days after implantation) was not possible because the implant consisted almost exclusively of a small volume (less than $30 \mu \mathrm{l}$ ) of the blood clot with few newly induced cellular elements that formed a very loose and fragile capsule around the clot. Northern blot analysis of the RNA extracted from a larger volume of blood clot did not reveal expression of the three bone-specific markers (data not shown). The expression of early (BSP) and late (OPN and OC) markers of bone differentiation in the wild-type mice (Fig. 5) was similar to that already described for the osteoinduction model in mice (Hirota et al, 1994): BSP mRNA levels decreased over time and were about $40 \%$ lower in $\mu \mathrm{MT}-/-$ than in the wild-type mice at all time points (Fig. 5). There was a 3-fold increase in OPN mRNA and 10-fold increase in OC mRNA with the differentiation of the ossicle in the wild-type mice, whereas this increase was much smaller in $\mu \mathrm{MT}-/-$ mice (Fig. 5).

For Northern blot analysis of BSP, OPN, and OC mRNA after bone marrow ablation, we isolated total RNA from the intact metaphysis and proximal diaphysis of the tibia. In this way we excluded cartilaginous tissue of the proximal growth plate from the sample but did not differentiate between the cortical and metaphyseal bone and diaphyseal contents. Although separate analysis of the diaphyseal content and cortical bone in the marrow ablation model has been described in the rat (Suva et al, 1993), mouse bones are 10 orders of magnitude smaller than in the rat and the separation of the two compartments is difficult. Moreover, after marrow ablation the formation of new bone starts as an activation of endosteal osteoblasts (Suva et al, 1993; Tanaka et al, 1996), so only a simultaneous analysis of the diaphyseal endosteal surface and the marrow content provides a complete insight into the cellular cascade following marrow ablation. The expression of BSP and OPN genes in

Table 1. Mass (mg) of Freshly Isolated Ossicles Induced by rhBMP-2 in $\mu$ MT-/- and Wild-Type Mice

\begin{tabular}{cccc}
\hline & & \multicolumn{2}{c}{ Time after rhBMP-2 implantation } \\
\cline { 3 - 4 } Type of tissue & Mouse & 7 days & 12 days \\
\hline Whole ossicle & Wild-type & $10.3 \pm 3.8$ & $7.0 \pm 2.6$ \\
& $\mu$ MT-/- & $20.3 \pm 5.5^{b}$ & $15.7 \pm 2.5^{c}$ \\
Newly induced tissue ${ }^{a}$ & Wild-type & $7.2 \pm 3.4$ & $6.3 \pm 2.5^{b}$ \\
& $\mu$ MT-/- & $15.6 \pm 6.1^{b}$ & $14.8 \pm 3.2^{c}$ \\
\hline
\end{tabular}

rhBMP-2, recombinant human bone morphogenetic protein; $\mu \mathrm{MT}-/-$, B-cell deficient gene knockout.

${ }^{a}$ Calculated from the wet weight of the whole, freshly isolated ossicle and the percentage of newly induced tissue (mesenchyme, cartilage, bone, and/or bone marrow) measured by histomorphometry ( $n=4$ mice per group).

${ }^{b}$ Statistically significant difference from the wild-type controls; $p=0.030$ for the whole ossicle and $p=0.049$ for the newly induced tissue.

${ }^{c}$ Statistically significant difference from the wild-type controls; $p=0.007$ for the whole ossicle and $p=0.011$ for the newly induced tissue. 

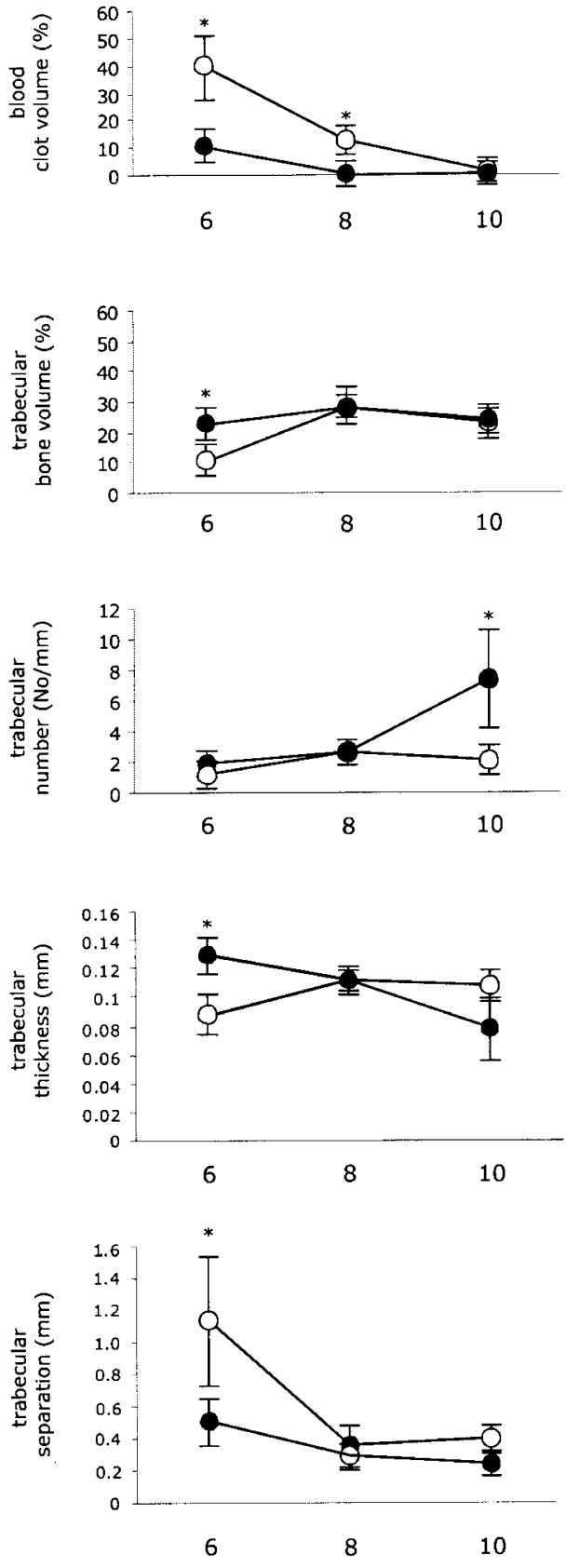

days

Figure 3.

Histomorphometry of new bone induced by bone marrow ablation in $\mu \mathrm{MT}-/-$ mice. Data are expressed as means \pm sD from 4 to 5 mice per group at each time point. Open circles, wild-type (C57BL/6J) mice; closed circles, mice homozygous for the $\mu \mathrm{MT}$ gene knockout ( $\mu \mathrm{MT}-/-)$.

intact preablation tibia was near the detection limit of the assay in both the wild-type and $\mu \mathrm{MT}-/-$ mice (Fig. $6)$. The preablation level of OC mRNA in $\mu \mathrm{MT}-/-$ mice was almost $80 \%$ lower than in the wild-type controls (Fig. 6). The activation pattern of BSP, OPN, and OC expression after ablation in the wild-type and $\mu \mathrm{MT}-/-$ mice was similar to that described in the rat model (Tanaka et al, 1996), with peak expression of all genes occurring 6 days after ablation (Fig. 6). At this time point, the greater volume of the newly induced bone in $\mu \mathrm{MT}-/-$ mice was paralleled by a greater BSP mRNA level compared with the wild-type controls (25-fold increase and 15-fold increase, respectively; Fig. 6). After the peak expression at 6 post-ablation days, the levels of BSP, OPN, and OC mRNA decreased more rapidly in $\mu \mathrm{MT}-/-$ mice than in the wild-type controls, so that at 10 post-ablation days the levels of mRNA for all three markers in $\mu \mathrm{MT}$-/- mice were at least half of those for the wild-type controls (Fig. 6).

Because new bone formation during the development and bone regeneration processes in the adult organism is governed by bone morphogenetic proteins (Wozney and Rosen, 1998), we next examined the expression of three BMPs (BMP-2, BMP-4, and BMP-7) by reverse transcription-polymerase chain reaction (RT-PCR). The optimization of primers and PCR reaction conditions, adjustment of the cycle number to the linear phase of PCR amplification (Fig. 7), negative and positive controls, and duplication of the same $\mathrm{PCR}$ reaction enabled us to use this technique for semiquantitative evaluation of mRNA expression (Lee and Lorenzo, 1999). In the model of endochondral osteogenesis induced by rhBMP-2, the levels of BMP-2, -4 , and -7 mRNAs were similar in implants from both wild-type and $\mu \mathrm{MT}-/-$ mice 7 days after implantation, and followed similar expression patterns: mRNA levels for BMP-2 and BMP-4 decreased, whereas the level of BMP-7 mRNA increased with the differentiation of the ossicle by the 12th postimplantation day (Fig. 8).

Semiquantitative RT-PCR analysis revealed that the mouse proximal tibia, ie, the metaphysis and diaphysis with the bone marrow, constitutively expressed BMP-2, -4, and -7 mRNA (Fig. 9). In wild-type mice, the cellular cascade of osteogenic regeneration after marrow ablation was paralleled by either unchanged or decreasing levels of BMPs mRNA, whereas marrow ablation in $\mu \mathrm{MT}-/-$ mice induced an increase in mRNA levels for all BMPs, especially at later time points (Fig. 9).

\section{Expression of Inflammatory Cytokines in Newly Formed Bone in $\mu$ MT-/- Mice}

We next analyzed the expression of TNF- $\alpha, \mathrm{IL}-1 \alpha$, $\mathrm{IL}-1 \beta$, and IL-6 during the new bone induction in $\mu \mathrm{MT}-/-$ mice. These cytokines play a role in the inflammatory reaction, which is an integral part of the osteoinduction sequence (Marusic et al, 1999; Urist, 1995), as well as in the regulation of proliferation, differentiation, and activity of both bone-forming and bone-resorbing cells (Rifas, 1999). In the model of osteoinduction by rhBMP-2, semiquantitative RT-PCR showed that TNF- $\alpha$, IL- $1 \alpha$, and IL- $1 \beta$ mRNA was expressed 7 days after implantation in the wild-type mice (Fig. 8). IL-6 mRNA could not be detected in implants from the wild-type mice at this time point, but was readily detectable 12 days after implantation (Fig. 8). In contrast to the lack of IL-6 expression in the wild-type mice, IL-6 mRNA was detected in implants at 7 post-implantation days, and the mRNA levels of 

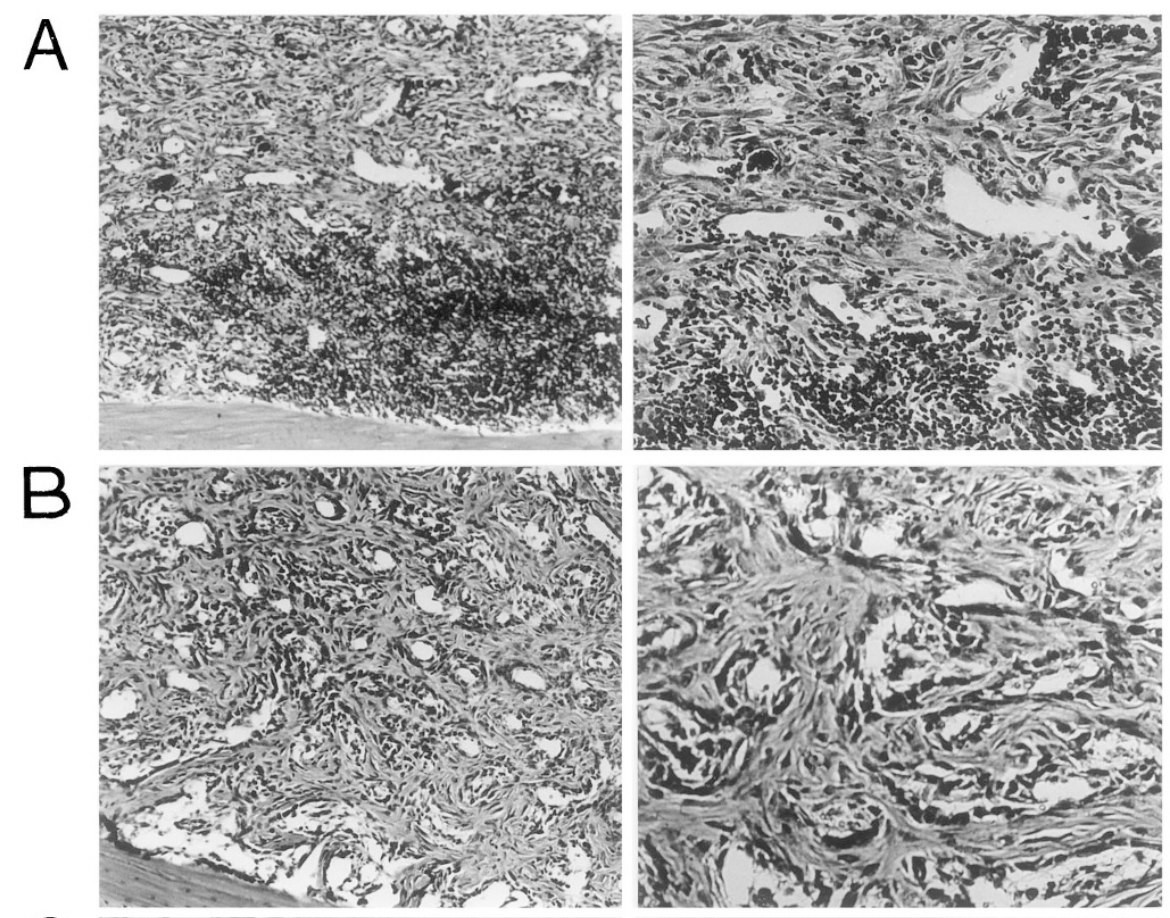

\section{$\mathrm{C}$}
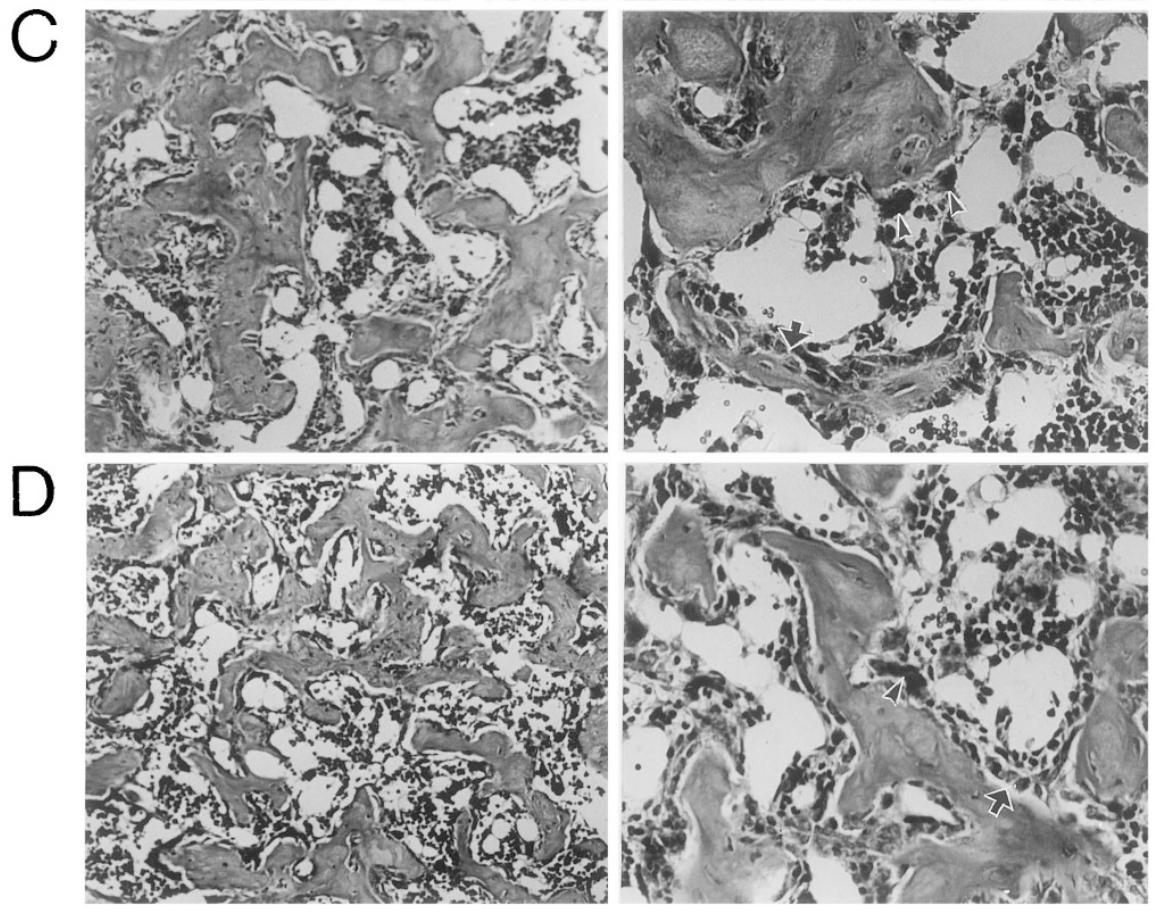

Figure 4.

Osteogenic regeneration after bone marrow ablation in $\mu \mathrm{MT}-/$ - mice. Six days after marrow ablation, the diaphyseal cavity of the tibiae from the wild-type mice was filled with a blood clot ( $A$, left panel) that had been partially replaced by proliferating mesenchyme ( $A$, right panel). At the same time point, the initial blood clot in the diaphyseal cavity of tibiae from $\mu \mathrm{MT}-/$ - mice underwent significantly faster resorption ( $B$, left panel) and the mesenchyme differentiated into osteoblasts lining newly formed trabeculae ( $B$, right pane). Ten days after marrow ablation, the diaphyseal cavity was completely filled with a network of trabecular bone in both groups $(C$ and $D)$. The volume of the newly formed trabeculae was similar in both groups, but $\mu \mathrm{MT}-/$ - mice had more numerous, but thinner, trabeculae $(C$, left panel compared with the wild-type mice ( $D$, left pane). In both groups, trabeculae were lined with active osteoblasts (arrows) and osteoclasts (arrowheads), and the intertrabecular space was filled with regenerating hematopoietic marrow $(C$ and $D$, right pane/s). Original magnification, $\times 100$ (left panels) or $\times 200($ right panels).

other cytokines were similar or greater than in the wild-type controls (Fig. 8). Cytokine expression decreased with the differentiation of the ossicle in $\mu \mathrm{MT}-/$ - mice, whereas mRNA level for cytokines in the wild-type controls either did not change (TNF- $\alpha$ ) or increased (IL-1 $\alpha$ and IL-1 $\beta$ ) with the differentiation of newly induced tissues (Fig. 8).

TNF- $\alpha$, IL- $1 \alpha$, and IL- $1 \beta$ were constitutively expressed in the tibiae of both wild-type and $\mu \mathrm{MT}-/-$ mice (Fig. 9). IL-6 mRNA expression in the intact 
A

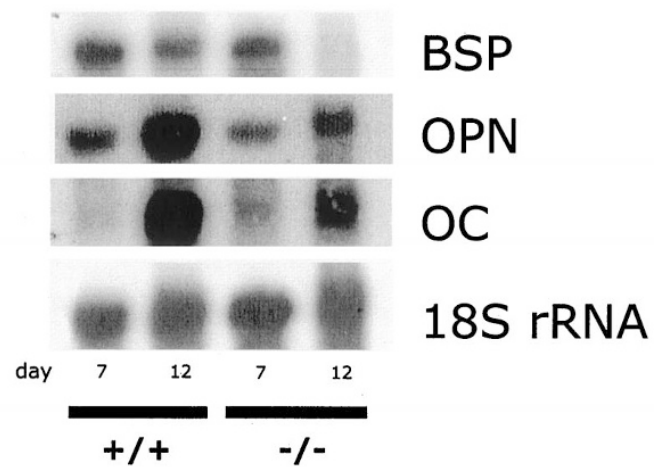

B

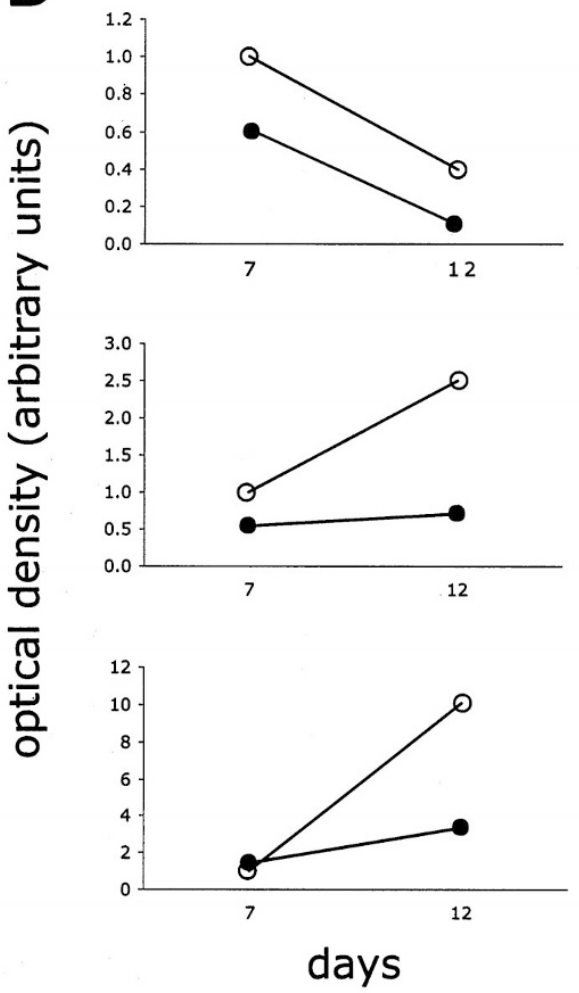

BSP

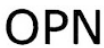

$\mathrm{OC}$

Figure 5.

Temporal expression pattern of osteoblast marker genes in implants induced by rhBMP-2 in $\mu \mathrm{MT}-/$ - mice. Northern blot analysis of bone specific protein (BSP), osteopontin (OP), and osteocalcin (OC) mRNA was carried out from total RNA samples prepared from implants collected at 7 and 12 days after the implantation of $5 \mu \mathrm{g}$ rhBMP-2 in a blood clot. A, Autoradiographs from a representative experiment; $+/+$, wild-type mice (C57BL/6); -/-, mice homozygous for the $\mu \mathrm{MT}$ gene knockout. $B$, Mean optical density ratio values of the Northern blot bands. Open circles, wild-type (C57BL/6J) mice; closed circles, mice homozygous for the $\mu \mathrm{MT}$ gene knockout ( $\mu \mathrm{MT}-/-)$. The optical density of each band was normalized to the optical density of 18S rRNA expression, and the basal mRNA expression at Day 7 of the wild-type mice was given a relative level of 1.0. The experiment was repeated twice with similar results (variation less than $10 \%$ ).

proximal tibia, as well as at all time points after marrow ablation, was below the detection limit of the RT-PCR assay, because the specific product could not be detected even after more than 40 amplification cycles under the same conditions as for the rhBMP-2 im-
A

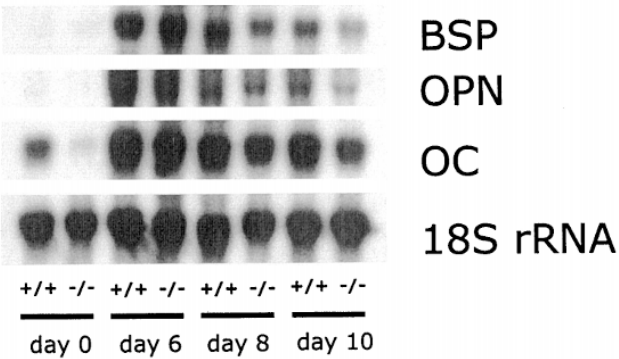

B

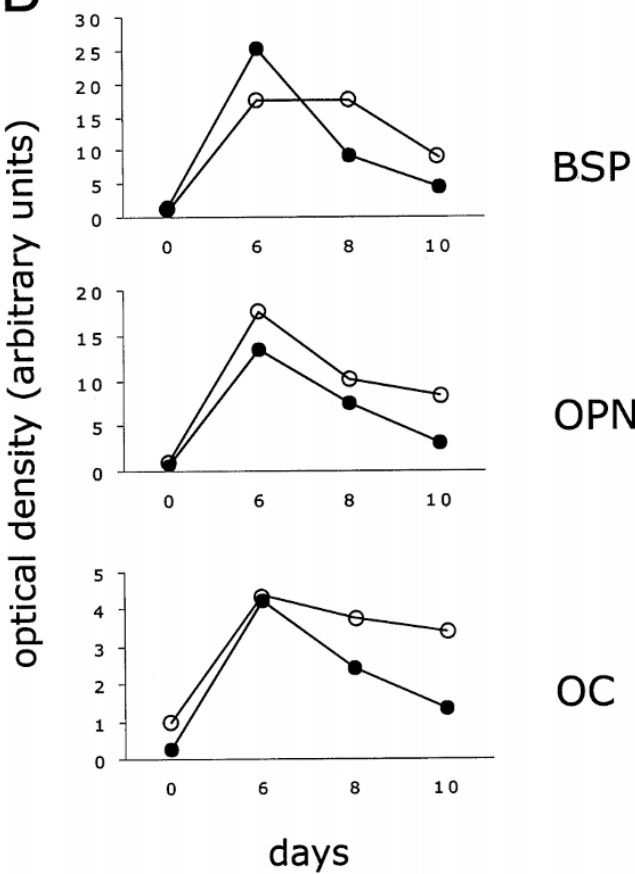

Figure 6.

Temporal expression pattern of osteoblast marker genes after bone marrow ablation in $\mu \mathrm{MT}-/-$ mice. Northern blot analysis of bone specific protein (BSP) osteopontin (OP), and osteocalcin (OC) mRNA was carried out from total RNA samples prepared from tibial shafts collected at Days $0,6,8$, and 10 after marrow ablation. $A$, Autoradiographs from a representative experiment; $+/+$, wild-type mice (C57BL/6); -/-, mice homozygous for the $\mu \mathrm{MT}$ gene knockout. $B$, Mean optical density ratio values of BSP, OP, and OC. Open circles, wild-type (C57BL/6J) mice; closed circles, mice homozygous for the $\mu \mathrm{MT}$ gene knockout ( $\mu \mathrm{MT}-/-)$. The optical density of each band was normalized to the optical density of 18S rRNA expression, and the basal mRNA expression at Day 0 of the wild-type mice was given a relative level of 1.0 . The experiment was repeated twice with similar results (variation less than $10 \%$ ).

plants (data not shown). The reasons for this are unclear but confirmed our earlier observation that IL-6 mRNA transcripts cannot be readily found in the mouse long bones and bone marrow, as opposed to mouse calvaria (Vargas et al, 1996). The level of TNF- $\alpha$ mRNA decreased with the osteogenic proliferation in the marrow cavity (Fig. 9) in both groups. The expression of IL-1 $\alpha$ mRNA did not significantly change after bone marrow ablation and the level of IL-1 $\beta$ mRNA slightly decreased from the 6th to the 10th postablation day in the wild-type mice (Fig. 9). In $\mu \mathrm{MT}-/-$ mice, the expression of IL- $1 \alpha$ and IL- $1 \beta$ increased with 


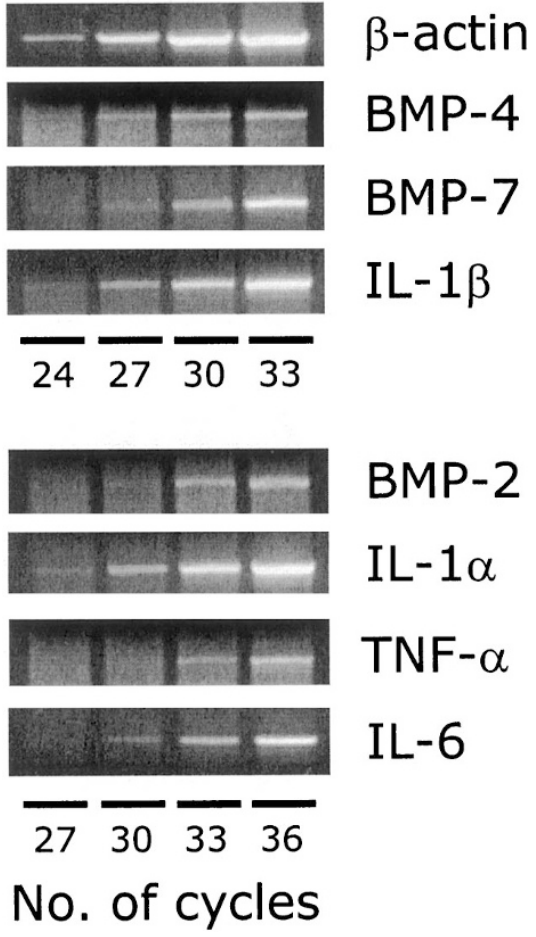

Figure 7.

PCR amplification for BMP-2, BMP-4, BMP-7, IL- $1 \alpha$ and $\beta$, TNF- $\alpha$, IL-6, and $\beta$-actin. PCR amplification was performed between 24 and 36 cycles, using the samples with the maximal expression of mRNA for each marker (see "Materials and Methods" section for detailed explanation). PCR amplifications were performed in triplicate, and representative gels are shown.

the formation and subsequent organization of cancellous bone in the marrow cavity (Fig. 9).

\section{Discussion}

The results of this study demonstrate that B lymphocytes may play a role in the regulation of new bone induction and regeneration in vivo. In the model of endochondral osteogenesis induced by rhBMP-2, the newly formed ossicles were significantly larger in mice without functional $B$ lymphocytes than in the wild-type controls. The similarity between the relative volumes of newly induced cartilage and bone in the two groups of mice indicates that the lack of B lymphocytes did not affect the differentiation potential of osteoprogenitor cells in the newly induced tissue but rather the recruitment and proliferation of chondrogenic and osteogenic progenitors in response to the implanted rhBMP-2. Similarly, in the model of osteogenic regeneration of bone marrow ablation, mice without $B$ lymphocytes resorbed the initial blood clot faster and replaced it with trabecular bone early after marrow injury, but they equaled the wild-type controls in the volume of newly formed bone at later time points. Both models of new bone induction have an important immunologic component. In the model of ectopic chondro-osteogenesis induced by rhBMPs or demineralized bone matrix, some degree of immune reaction is necessary for the initiation of the osteoinductive cellular cascade after the implantation of bone matrix or bone morphogenetic protein(s) (Urist, 1995). Macrophages accumulate next to the demineralized bone matrix early after implantation in vivo, and BMPs can induce directed migration of monocytes at femtomolar concentrations in vitro (Cunningham et al, 1992), suggesting that a key step in bone induction is the chemotaxis of monocytes in response to BMPs. BMPs also stimulate the expression of TGF- $\beta$ in monocytes (Cunningham et al, 1992), which in turn stimulates bone formation and the additional expression of BMPs themselves (Wozney and Rosen, 1998). In the model of bone marrow ablation, mechanical removal of the marrow is followed by clot formation, infiltration of monocytes and lymphocytes, and expression of BMP-4 and BMP receptors (Shimizu et al, 1998). In terms of the present study, it seems that the lack of $B$ lymphocytes created a change in the immunological milieu of the local osteoinductive sequence, which stimulated the initial accumulation and proliferation of mesenchymal progenitor cells. Increased expression of bone sialoprotein, an early bone-specific marker, in $\mu \mathrm{MT}$ knockout mice at the same time that these mice resorbed more blood clot and formed more trabecular bone after marrow ablation, also argues for an early effect on osteogenesis. Hematopoietic cells carry BMP receptors and produce BMPs (Bhatia et al, 1999; Detmer et al, 1999) and may thus be involved in bone morphogenesis. Evidence for the importance of lymphocytes in the early phases of osteoinduction also comes from studies of fibrodysplasia ossificans progressiva. In one study, disabling ectopic osteogenesis was associated with an overexpression of BMP-4 in lymphocytes (Shafritz et al, 1996), and in another, the earliest lesions were characterized by acute infiltration of both B and T lymphocytes (Gannon et al, 1998).

The source and nature of the signals by which $B$ lymphocytes could influence the proliferation of mesenchymal cartilage and bone precursor cells are only a matter of conjecture at this stage. Many in vitro studies have documented the importance of individual cytokines and local growth factors for the function of both osteoclasts and osteoblasts (Rifas, 1999). IL-1 and TNF are potent stimulators of bone resorption (Rifas, 1999) and are also involved in the regulation of bone formation (Frost et al, 1997). IL-6 acts as a downstream cytokine induced by IL-1 and TNF and stimulates both osteoclastogenesis (Jilka et al, 1992) and osteoblastogenesis (Bellido et al, 1997). In the in vivo situation, there are likely very complex interactions between immunological and bone cells, and sorting out the contributions of individual factors is difficult. For this reason, we did not analyze the expression of individual cytokines but rather followed the profile of cytokines and bone-related factors expressed during new bone induction. The cytokine expression pattern during both types of osteogenesis changed in the absence of $B$ lymphocytes. During endochondral osteogenesis induced by rhBMP-2, the expression of IL- $1 \alpha$ and $\beta$, TNF- $\alpha$, and IL- 6 , increased with the differentiation of the ossicle in the wild-type mice, but decreased in $\mu \mathrm{MT}$ knockout mice. As these cytokines may play a role in both the initial cell 


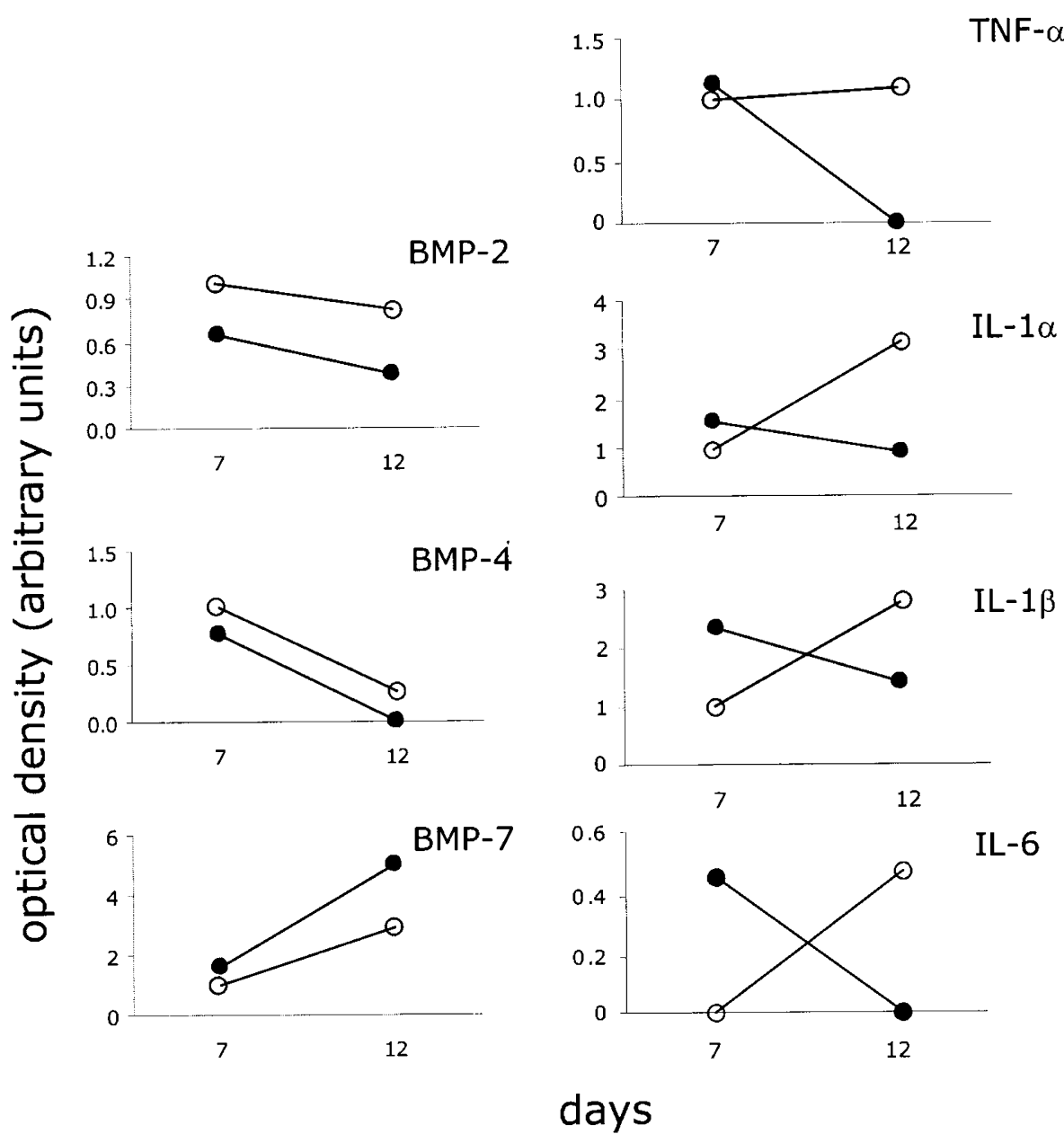

Figure 8.

Temporal expression pattern of mRNA for bone morphogenetic proteins (BMP-2, BMP-4, and BMP-7) and cytokines (IL- $1 \alpha$ and $\beta$, TNF- $\alpha$, and IL-6) in implants induced by rhBMP-2 in $\mu$ MT-/- mice. RT-PCR analysis was carried out from total RNA samples prepared from implants collected at Days 7 and 12 after implantation of $5 \mu \mathrm{g}$ rhBMP-2. Open circles, wild-type (C57BL/6J) mice; closed circles, mice homozygous for the $\mu \mathrm{MT}$ gene knockout ( $\mu \mathrm{MT}-/-)$. The results are expressed as mean optical density ratio values of PCR bands. The optical density of each band was normalized to the optical density of $\beta$-actin expression and the basal mRNA expression at Day 7 of the wild-type mice was given a relative level of 1.0. The experiment was repeated twice with similar results (variation less than 10\%). BMP-4, BMP-7, IL- $1 \alpha$, and IL- $1 \beta$ were amplified for 30 cycles; BMP-2, TNF- $\alpha$, and IL-6 for 33 cycles; and $\beta$-actin for 27 cycles.

chemotaxis during osteogenesis and the osteoclastic resorption that finally remodels the ossicle, the differences observed in the cytokine expression pattern may be related to the alteration in either or both of these processes in mice with a $\mu \mathrm{MT}$ knockout. Changed cytokine expression pattern in $\mu \mathrm{MT}$ knockout mice during the early phases of bone induction may be a reflection of the altered immunological milieu, which facilitates early attraction and proliferation of chondro- and/or osteoprogenitor cells. The role of these cytokines in osteoclast differentiation and activation at later stages of the osteoinduction sequence needs further investigation.

The change in the cytokine expression pattern during osteogenic regeneration after bone marrow ablation in $\mu \mathrm{MT}$ knockout mice had an opposite direction than in the model of endochondral osteogenesis. This is not surprising because the local immunologic/hematopoietic environment in the bone marrow differs from that of subcutaneus tissue where endochondral osteogenesis is induced by rhBMP-2. $\mu \mathrm{MT}$ knockout mice showed a constant increase in $\mathrm{IL}-1 \alpha$ and $\beta$ expression and a small change in TNF- $\alpha$ expression during the first 10 days after marrow ablation, compared with either unchanged or decreasing expression of those cytokines in the wild-type controls. Since IL-1 isoforms and TNF have been implicated in normal hematopoiesis (Dinarello, 1991), the alterations observed in $\mu \mathrm{MT}$ knockout mice may reflect altered regeneration of the marrow that repopulates the resorbing trabecular network in the diaphysis, compensating for the lack of B-lymphopoiesis. The differences between the wild-type and $\mu \mathrm{MT}$ knockout mice in the expression of BMPs were similar to those in cytokine expression, and could reflect their involvement in hematopoiesis (Bhaita et al, 1999). It is also possible that the change in the cytokine expression pattern in $\mu \mathrm{MT}$ knockout mice was related to the alteration in osteoclast differentiation and activation during bone marrow regeneration. Our study addressed mostly bone formation because the amount of bone at 10 days after marrow ablation, the final time 


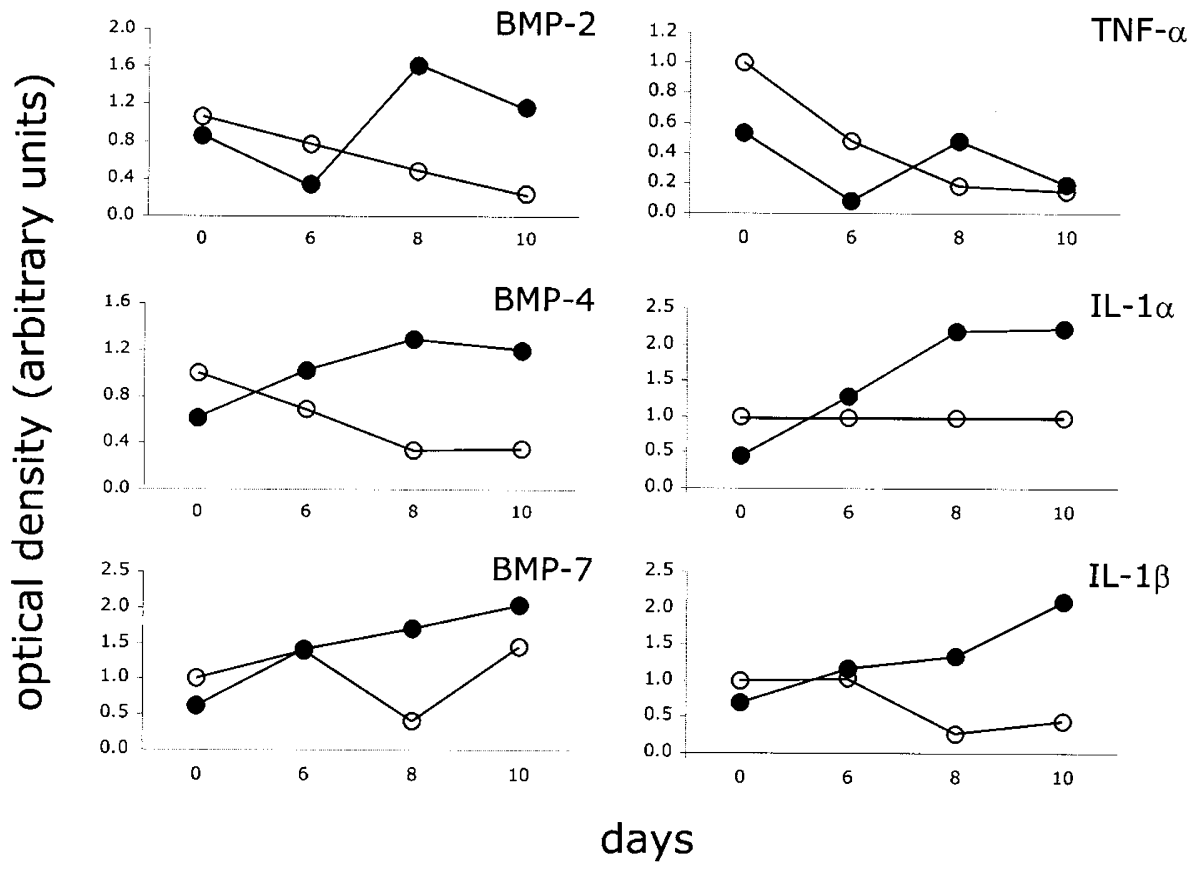

Figure 9.

Temporal expression pattern of mRNA for bone morphogenetic proteins (BMP-2, BMP-4, and BMP-7) and cytokines (IL- $1 \alpha$ and $\beta$, and TNF- $\alpha$ ) after bone marrow ablation in $\mu \mathrm{MT}$-/- mice. RT-PCR analysis was carried out from total RNA samples prepared from tibial shafts collected at Days $0,6,8$, and 10 after marrow ablation. Open circles, wild-type (C57BL/6J) mice; closed circles, mice homozygous for the $\mu \mathrm{MT}$ gene knockout ( $\mu \mathrm{MT}-/-)$. The results are expressed as mean optical density ratio values of PCR bands. The optical density of each band was normalized to the optical density of $\beta$-actin expression, and the basal mRNA expression at Day 7 of the wild-type mice was given a relative level of 1.0. The experiment was repeated twice with similar results (variation less than $10 \%$ ). BMP-4, BMP-7, IL-1 $\alpha$, and IL-1 $\beta$ were amplified for 30 cycles; BMP-2 and TNF- $\alpha$ for 33 cycles; and $\beta$-actin for 27 cycles.

point that followed in our study, was unchanged in comparison with the previous time point, and extensive resorption was still not evident. However, the change from thick and less separated trabeculae on the 6th post-ablation day to more numerous, but thinner, trabeculae on the 10th post-ablation day, as well as decreased expression of bone-specific markers at later time points in $\mu \mathrm{MT}$ knockout mice compared to the wild-type controls, argues that these mice may also differ in the resorption and remodeling of the trabecular network. An ongoing study in our laboratory evaluates the number of osteoclasts and their resorptive activity at later time points, when the diaphyseal marrow space is reconstituted by a complete resorption of the trabecular network (Suva et al, 1993; Tanaka et al, 1996).

In conclusion, our study demonstrated that the induction of new bone formation in an adult organism in vivo has an important immunologic aspect involving $B$ lymphocytes. The stimulation of the initial steps in the osteoinduction cellular sequence observed in $\mu \mathrm{MT}$ knockout mice may be explained by a general disequilibrium of the immunological system in the absence of $B$ lymphocytes, because it is well known that the depletion of B lymphocytes down-regulates the humoral (Th2) immunity and shifts the immune reaction towards inflammatory and cell-mediated (Th1) response (Abbas et al, 1996). Such change in the local lymphocyte and other immune cell populations and their activity may facilitate the migration and proliferation of mesenchyme precursors in response to an osteoinductive stimulus. Further studies at the molecular level in vivo will be essential to elucidate the possible roles and interactions of B lymphocytes with other cell populations in the regulation of bone mass. Gaining an understanding of these processes will be an important step in the identification of molecular defects in many pathological states involving hematopoietic and bone systems, such as hematological malignancies, immunodeficient disorders, and osteoporosis.

\section{Methods}

\section{Mice}

Mice homozygous for the $\mu \mathrm{MT}$ gene knockout were produced by gene targeting (Kitamura et al, 1991). Briefly, $\mu \mathrm{MT}$ knockout mice were generated by disrupting an exon of the gene encoding the IgM heavy chain ( $\mu$-chain) constant region, thus arresting the development of B-cells at the stage of large pre-Bcell. The original strain of $\mu \mathrm{MT}$ knockout mice was from a C57BL/6 $\times 129 / S v$ genetic background. The mice were subsequently backcrossed for more than 15 generations onto a C57BL/6 background so that C57BL/6 mice were used as the wild-type control. Mice were bred from the original stock (Kitamura et al, 1991) and maintained by Stipan Jonjic at the Department of Histology and Embryology of Rijeka University in Rijeka, Croatia. Animals were kept in a pathogenfree environment in groups of three to four per cage under conditions of 14 hours light and 10 hours 
darkness, ambient temperature of $20 \pm 2^{\circ} \mathrm{C}$, and water and pelleted diet (PLIVA, Zagreb, Croatia) ad libitum. Maintenance of the animals and experimental procedures followed the United States National Institutes of Health (NIH) Guide for the Care and Use of Laboratory Animals (National Institutes of Health, 1996). Female mice, 12 weeks of age, were used in all experiments. Wild-type $(+/+)$ and $\mu \mathrm{MT}-/-$ homozygous litter mates were selected from the progeny of $\mu \mathrm{MT}+/$ - heterozygous parents by testing for the presence of IgM antibodies in the serum, using enzymelinked immunosorbent assay with antimouse antibodies (Polic et al, 1998). Mice without detectable IgM antibodies $(<0.1 \mu \mathrm{g} / \mathrm{ml})$ were considered homozygous for the $\mu \mathrm{MT}$ mutation (Kitamura et al, 1991), compared with $>300 \mu \mathrm{g} / \mathrm{ml}$ in wild-type animals. All animal protocols were approved by the Ethics Committee of the Zagreb University School of Medicine.

\section{Bone Induction by rhBMP-2}

Recombinant human (rh) BMP-2 was a gift from the Genetics Institute, Cambridge, Massachusetts. Five $\mu \mathrm{g}$ of rhBMP-2 were mixed with $50 \mu \mathrm{l}$ of blood from syngeneic mice and allowed to form a firm clot in a 1.5 $\mathrm{ml}$ tube. After setting at room temperature for 1 hour, the clot was implanted subcutaneously and bilaterally in the pectoral region of mice anesthetized with tribromoethanol (Aldrich, Milwaukee, Wisconsin) (Marusic et al, 1999). The implantation of blood clot alone, without added rhBMP-2, does not induce new tissue and the clot is completely resorbed by day 10 (Lukic IK and Marusic A, unpublished data). Implants were dissected out 7 and 12 days after implantation. Implants from one side were processed for histology. Implants from the contralateral side were extracted for total RNA, which was examined by Northern blot and RT-PCR analysis.

\section{Bone Marrow Ablation}

Tibial bone marrow ablation was performed under general anesthesia with tribromoethanol, according to the protocol described for the rat model (Suva et al, 1993). Using the paraligamental approach, a longitudinal incision was made to expose the tibial condyles. A $1 \mathrm{~mm}$ hole was made at the intercondylar area with a surgical drill, and a 26 gauge needle was inserted into the marrow cavity. The marrow was aspirated by vacuum suction, followed by irrigation with sterile saline, using a syringe with a 26 gauge needle. The skin was closed with silk sutures. Mice were killed by cervical dislocation following $\mathrm{CO}_{2}$ anesthesia at 6, 8, and 10 days after ablation, and tibiae were processed for histology or RNA was extracted for Northern blot and RT-PCR analysis. Contralateral tibiae were used as controls (Day 0) (Shimizu et al, 1998; Suva et al, 1993).

\section{Histological Analysis}

Implants and tibiae were fixed in 4\% buffered formaldehyde at $4^{\circ} \mathrm{C}$ and decalcified with $14 \%$ ethylene- diamine tetraacetic acid (EDTA) in 3\% formalin (2 days for implants and 7 days for the tibiae). They were then dehydrated in increasing alcohol concentrations and embedded in paraffin. Implants were cut serially into 6- $\mu \mathrm{m}$ thick sections with a standard microtome (Leica, Nussloch, Germany) and stained with Goldner's trichrome stain. Histomorphometry measurements were performed under the light microscope $(\times 20$ magnification) by a blinded observer. For the rhBMP-2 implants, the volume of the newly formed tissue was measured on serial sections (every 10th section throughout the thickness of the whole specimen) by counting points of a Merck ocular grid (Merck, Darmstadt, Germany) over bone, bone marrow space, cartilage, mesenchyme, and implanted blood clot (Marusic et al, 1999). For histomorphometric analysis of the tibiae, frontal sections through the intercondylar eminence were used. Using a software package for image analysis (Issa; VAMS, Zagreb, Croatia) the following parameters were measured (Parfitt et al, 1987): total tissue area (diaphyseal/marrow cavity from the distal end of the metaphysis to the tibiofibular junction), trabecular perimeter, trabecular area, and clot area. Percent of trabecular area, percent of clot area, trabecular number, trabecular thickness, and trabecular separation were calculated from directly measured values. The measured area began $1 \mathrm{~mm}$ from the epiphyseal growth plate to exclude the primary spongiosa and covered the whole diaphyseal shaft to the end of the hemorrhage produced by marrow ablation. Measurements were performed on three nonconsecutive sections from each animal and their mean was taken for further analysis.

\section{RNA Preparation}

rhBMP-2 implants were dissected out from loose subcutaneous connective tissue. In the bone marrow ablation model, the distal end and proximal epiphyseal plate of the tibia were excised. Care was taken to excise all connective and muscular tissue around the specimens, so that only the tissue enclosed by bone would serve as a source for RNA. Both types of specimens were immersed in liquid nitrogen and homogenized by a hard tissue homogenizer, and total RNA was extracted from the implants or tibiae using a commercial kit (TRI-REAGENT; Molecular Research Center, Cincinnati, Ohio). The purity of RNA preparations was monitored by the ratio of absorbance at 260 and $280 \mathrm{~nm}$, which was generally between 1.7 and 1.9. Each bone RNA sample was prepared from a pool of 5 implants or 3 tibiae.

\section{Northern Blot Analysis}

Total RNA (10 $\mu \mathrm{g}$ of each sample) was fractionated on a $1.5 \%$ agarose, $1.1 \mathrm{mmol} / \mathrm{L}$ formaldehyde gel and transferred by capillary pressure to a nylon membrane. The bound RNA was cross-linked by UV light (UV Stratalinker; Stratagene, La Jolla, California). The probes were generated using previously published primers for mouse osteopontin (Craig et al, 1989), 
mouse bone sialoprotein (Young et al, 1994), and mouse osteocalcin (Celeste et al, 1986). PCRgenerated probes were labeled with ${ }^{32} \mathrm{P}$-dCTP using the random primer labeling method (BRL, Gaithersburg, Maryland) and then hybridized at $42^{\circ} \mathrm{C}$ in $50 \%$ formamide, $5 \times$ SSPE $(1 \times$ SSPE $=0.149 \mathrm{mmol} / \mathrm{L}$ $\mathrm{NaCl}, 10 \mathrm{mmol} / \mathrm{L} \mathrm{NaH}_{2} \mathrm{PO}_{4}, 1 \mathrm{mmol} / \mathrm{L}$ EDTA, pH 7.4), $1.2 \times$ Denhardt's solution, $0.5 \%$ sodium dodecyl sulfate (SDS), and $100 \mu \mathrm{g} / \mathrm{ml}$ salmon sperm DNA. Radioactive probes were added at $1-5 \times 10^{6} \mathrm{cpm} / \mathrm{ml}$. After hybridization, the blots were washed in buffers of increasing stringency: $6 \times$ SSPE and $0.5 \%$ SDS at room temperature for 10 minutes; $0.1 \times$ SSPE and $0.1 \% \mathrm{SDS}$ at $37^{\circ} \mathrm{C}$ for 10 minutes; and $0.1 \times \mathrm{SSPE}$ and $0.1 \%$ SDS at $65^{\circ} \mathrm{C}$ for 10 minutes. Autoradiography was done by exposing the membrane to x-ray film (RP X-Omat; Eastman Kodak, Rochester, New York) with intensifying screens at $-70^{\circ} \mathrm{C}$. Northern blot autoradiographs were analyzed by laser densitometry. The densitometry readings for specific probes were normalized for variations in gel loading by dividing their optical density (OD) readings by $18 \mathrm{~S}$ rRNA OD readings, after correction for the background. These values were then normalized to the value for the wild-type mice (Day 7 for rhBMP-2 implants and control tibiae (Day 0) in marrow ablation model) (Shimizu et al, 1998; Suva et al, 1993) to semiquantitatively assess the differences in the expression level. RNA samples from two independent experiments gave similar patterns of gene expression in repeated blots.

\section{Polymerase Chain Reaction Amplification}

Ten $\mu \mathrm{g}$ of total RNA was converted to cDNA by reverse transcriptase (Superscript II; Gibco, Grand Island, New York). An initial reverse transcription mixture of the total RNA, random hexamer, and RNAse inhibitors was incubated at $70^{\circ} \mathrm{C}$ and then quenched on ice before the addition of the RT buffer $(50 \mathrm{mmol} / \mathrm{L}$ Tris- $\mathrm{HCl}, \mathrm{pH} 8.3,75 \mathrm{mmol} / \mathrm{L} \mathrm{KCl}, 3 \mathrm{mmol} / \mathrm{L} \mathrm{MgCl}_{2}$ ), deoxyribonucleoside triphosphates (dNTPs), dithiothreitol (DTT), and reverse transcriptase. The final mixture was incubated for 1 hour at $37^{\circ} \mathrm{C}$, pulsed with reverse transcriptase, and incubated for another 1 hour at $37^{\circ} \mathrm{C}$. The amount of cDNA corresponding to
$0.5 \mu \mathrm{g}$ of the reversely transcribed RNA was amplified by PCR with a hot start procedure by adding Taqpolymerase (Amplitaq; Perkin Elmer, Norwalk, Connecticut) to the PCR mixture during the last minute of the 5-minute heating at $94^{\circ} \mathrm{C}$. PCR was performed in a thermal cycler (GeneAmp PCR System 2400, Perkin Elmer) using the following cycles: denaturation at $94^{\circ} \mathrm{C}$ for 30 seconds; primer annealing at $65^{\circ} \mathrm{C}$ for 45 seconds; and extension at $72^{\circ} \mathrm{C}$ for 60 seconds. After the last cycle, the mixture was incubated at $72^{\circ} \mathrm{C}$ for 7 minutes.

Specific amplimer sets for murine bone morphogenetic protein 2 (BMP-2), BMP-4, and BMP-7 antisense and sense were a kind gift from the Genetics Institute, Cambridge, Massachusetts. Other amplimer sets were designed from published cDNA sequences (Table 2): interleukin-1 $\alpha$ (IL-1 $\alpha$ ) (Lomedico et al, 1984) and $\beta$ (IL-1 $\beta$ ) (Gray et al, 1986), tumor necrosis factor- $\alpha$ (TNF- $\alpha$ ) (Pennica et al, 1985), interleukin-6 (IL-6) (Van Snick et al, 1988), and $\beta$-actin (Alonso et al, 1986) antisense and sense. The specificity of the primers was checked by Southern blot. Primers were chosen to be approximately 18 to 22 bases in length and more than $50 \%$ cytosine and guanine (GC) in content. They resided in separate exons to inhibit amplification of the genomic sequence and to make the size difference between the mRNA and genomic product easily discernible. Negative controls of the reverse transcription and PCR procedures, as well as positive controls, were run in parallel to the experimental samples. For each time point, RT was performed on RNA isolated from two independent experiments, and PCR was performed in duplicate for each cDNA, to insure the reproducibility of the assay. To verify that amplifications were in the linear range of each PCR analysis, we performed PCR amplifications of up to 36 cycles, using cDNA from samples with maximal expression of individual factors (Lee and Lorenzo, 1999): wild-type preablation tibiae for $\beta$-actin and TNF- $\alpha$; tibiae from $\mu \mathrm{MT}-/-$ mice 10 days after marrow ablation for IL-1 $\alpha$, IL-1 $\beta$, and BMPs; and ossicles from the wild-type mice 12 days after implantation for IL-6. $\beta$-Actin was amplified at 27 cycles; BMP-4, BMP-7, IL-1 $\alpha$, and $\mathrm{IL}-1 \beta$ at 30 cycles; and BMP-2, TNF- $\alpha$, and IL- 6 at 33 cycles (Fig. 7). The amplified products were run in a $1.5 \%$ agarose gels, stained with ethidium bromide,

Table 2. Description of PCR Primers

\begin{tabular}{lcll}
\hline Target & $\begin{array}{c}\text { Product } \\
\text { size }(\mathrm{bp})\end{array}$ & \multicolumn{1}{c}{ 5' sequence (Sense: 5' to 3') } & 3' sequence (Antisense: 5' to 3') \\
\hline BMP-2 & 231 & GGGAAACAGTAGTTTCCAGC & ACACCTGGGTTCTCCTCTAA \\
BMP-4 & 280 & GAACATCTGGAGAACATCCC & ACATCGAAAGTTCCCACCG \\
BMP-7 & 173 & ATGTTCATGTTGGACCTGTA & AGGTTGACGAAGCTCATGAC \\
TNF- $\alpha$ & 692 & CTCAGGCCCGTCCAGATGAAACC & ATGAGCACAGAAAGCATGATCCGC \\
IL-1 $\alpha$ & 625 & ATGGCCAAAGTTCCTGACTTGTTT & CCTTCAGCAACACGGGCTGGTC \\
IL-1 $\beta$ & 563 & ATGGCAACTGTTCCTGAACTCAACT & CAGGACAGGTATAGATTCTTTCCTTT \\
IL-6 & 638 & ATGAAGTTCCTCTCTGCAAGAGACT & CACTAGGTTTGCCGAGTAGATCTC \\
$\beta$-actin & 540 & GTGGGCCGCTCTAGGCACCAA & CTCTTTGATGTCACGCACGATTTC \\
\hline
\end{tabular}

PCR, polymerase chain reaction; bp, base pair; BMP, bone morphogenetic protein; TNF- $\alpha$, tumor necrosis factor- $\alpha$; IL-1 $\alpha$, interleukin-1 $\alpha$; IL-1 $\beta$, interleukin-1 $\beta$; IL-6, interleukin-6. 
and photographed under UV illumination. Images were scanned and optical density was determined using a digital image processing and analysis program (Scion Image, Scion Corporation, Frederick, Maryland). The densitometry readings for specific probes were normalized by dividing their optical density readings by $\beta$-actin readings, after correction for the background. These values were then normalized to the value for the wild-type mice, Day 7 for rhBMP-2 implants and Day 0 for unablated tibiae in the marrow ablation model, to semiquantitatively assess the differences in the expression level. RNA samples from two independent experiments gave the same pattern of gene expression in repeated PCR runs.

\section{Statistical Analysis}

The data were expressed as mean \pm standard deviation of four to six mice per group. The results were compared using Student's $t$ test after establishing homogeneity of variances and normal distribution of data. The differences between $\mu \mathrm{MT}-/-$ and wild-type mice were considered statistically significant if $p \leq$ 0.05 .

\section{Acknowledgement}

We are indebted to the Genetics Institute of Cambridge, Massachusetts, for the gift of rhBMP-2 and PCR primers for the bone morphogenetic proteins.

\section{References}

Abbas AK, Murphy KM, and Sher A (1996). Functional diversity of helper T lymphocytes. Nature 381:787-793.

Alonso S, Minty A, Bourlet Y, and Buckingham M (1986). Comparison of the three actin-coding sequences in the mouse: Evolutionary relationships between the actin genes of warm-blooded vertebrates. J Mol Evol 23:11-22.

Bellido T, Borba VZC, Robertson P, and Manolagas SC (1997). Activation of JAK/STAT signal transduction by IL-6 type cytokines promotes osteoblast differentiation. Endocrinology 138:3666-3676.

Bhatia M, Bonnet D, Wu D, Murdoch B, Wrana J, Gallacher L, and Dick JE (1999). Bone morphogenetic proteins regulate the developmental program of human hematopoietic stem cells. J Exp Med 189:1139-1148.

Buchinsky FJ, Ma Y, Mann GN, Rucinski B, Bryer HP, Paynton BV, Jee WSS, Hendy GN, and Epstein S (1995). Bone mineral metabolism in $\mathrm{T}$ lymphocyte-deficient and -replete strains of rat. J Bone Miner Res 10:1556-1565.

Celeste AJ, Buecker JL, Kriz R, Wang EA, and Wozney JM (1986). Isolation of the human gene for bone gla protein utilizing mouse and rat cDNA clones. EMBO J 5:1885-1890.

Craig AM, Smith JH, and Denhardt DT (1989). Osteopontin, a transformation-associated adhesion phosphoprotein, is induced by 12-O-tetradecanoylphorbol 13-acetate in mouse epidermis. J Biol Chem 264:9682-9689.
Cunningham ND, Paralkar V, and Reddi AH (1992). Osteogenin and recombinant bone morphogenetic protein $2 \mathrm{~B}$ are chemotactic for human monocytes and stimulate transforming growth factor $\beta 1$ mRNA expression. Proc Natl Acad Sci USA 89:11740-11744.

Detmer K, Steele TA, Shoop MA, and Dannawi H (1999). Lineage-restricted expression of bone morphogenetic protein genes in human hematopoietic cell lines. Blood Cells Mol Dis 25:310-323.

Dexter TM, Allen TD, and Lajtha LG (1977). Conditions controlling the proliferation of hematopoietic stem cells in vitro. J Cell Physiol 91:335-344.

Dinarello CA (1991). Interleukin-1 and interleukin-1 antagonism. Blood 77:1627-1652.

Encina NR, Billotte WG, and Hofmann M-CC (1999). Immunomagnetic isolation of osteoprogenitors from human bone marrow stroma. Lab Invest 79:449-457.

Franzoso G, Carlson L, Xing L, Poljak L, Shores EW, Brown KD, Leonardi A, Tran T, Boyce BF, and Siebenlist U (1997). Requirement for NF-kappaB in osteoclast and B-cell development. Genes Dev 11:3482-3496.

Frost A, Jonsson KB, Nilsson O, and Ljunggren O (1997). Inflammatory cytokines regulate proliferation of cultured human osteoblasts. Acta Orthop Scand 68:91-96.

Gannon FH, Valentine BA, Shore EM, Zasloff MA, and Kaplan FS (1998). Acute lymphocytic infiltration in an extremely early lesion of fibrodysplasia ossificans progressiva. Clin Orthop 346:19-25.

Gray PW, Glaister D, Chen E, Goeddel DV, and Pennica D (1986). Two interleukin 1 genes in the mouse: Cloning and expression of the cDNA for murine interleukin 1 beta. $\mathrm{J} \mathrm{Im-}$ munol 137:3644-3648.

Hirota S, Takaoka K, Hashimoto J, Nakase T, Takemura T, Morii E, Fukuyama A, Morihana K, Kitamura Y, and Nomura S (1994). Expression of mRNA for murine bone-related proteins in ectopic bone induced by murine morphogenetic protein- 4 . Cell Tissue Res 277:27-32.

Jilka RL, Hangoc G, Girasole G, Passeri G, Williams DC, Abrams SA, Boyce B, Broxmeyer $\mathrm{H}$, and Manolagas SC (1992). Increased osteoclast development after estrogen loss: Mediation by interleukin-6. Science 257:88-91.

Jimi E, Nakamura I, Ikebe T, Akiyama S, Takahashi N, and Suda T (1998). Activation of NF-kappaB is involved in the survival of osteoclasts promoted by interleukin 1. J Biol Chem 15:8799-8805.

Kitamura D, Roes J, Kuehn R, and Rajewsky K (1991). A B-cell deficient mouse by targeted disruption of the membrane exon of the immunoglobulin $\mu$ chain gene. Nature 350:423-426.

Lee S-K and Lorenzo JA (1999). Parathyroid hormone stimulates TRANCE and inhibits osteoprotegerin mRNA expression in bone marrow cultures: Correlation with osteoclast-like cell formation. Endocrinology 140:3552-3561.

Lomedico PT, Gubler U, Hellmann CP, Dukovich M, Giri JG, Pan Y-CE, Collier K, Semionow R, Chua AO, and Mizel SB (1984). Cloning and expression of murine interleukin-1 cDNA in Escherichia coli. Nature 312:458-462.

Marusic A, Dikic I, Vukicevic S, and Marusic M (1992). New bone induction by demineralized bone matrix in immunosuppressed rats. Experientia 48:783-785. 
Marusic A, Grcevic D, and Katavic V (1996). New bone induction by bone matrix and recombinant human bone morphogenetic protein-2 in the mouse. Croat Med J 37:237244.

Marusic A, Katavic V, Grcevic D, and Lukic IK (1999). Genetic variability of new bone induction in mice. Bone 25:25-32.

Marusic A, Katavic V, Stimac D, Kusec V, and Jonjic S (1995). Bone turnover in homozygous $\beta 2$-microglobulin knock-out mice does not differ from that of their heterozygous littermates. Eur J Clin Chem Clin Biochem 33:915-918.

Masuzawa T, Miyaura C, Onoe Y, Kusano K, Ohta H, Nozawa S, and Suda T (1994). Estrogen deficiency stimulates B-lymphopoiesis in mouse bone marrow. J Clin Invest 94: 1090-1097.

McCauley LK, Rosol TJ, Capen CC, and Horton JE (1989). A comparison of bone turnover in athymic (nude) and euthymic mice: Biochemical, histomorphometric, bone ash and in vitro studies. Bone 10:29-34.

Miyaura C, Onoe Y, Inada M, Maki K, Ikuta K, Ito M, and Suda $T$ (1997). Increased B-lymphopoiesis by interleukin 7 induces bone loss in mice with intact ovarian function: Similarity to estrogen deficiency. Proc Natl Acad Sci USA 94:9360-9365.

National Institutes of Health (1996). Guide for the care and use of laboratory animals. U.S. Department of Health and Human Services. Bethesda, Maryland: National Institutes of Health, publication no. 93-23.

Nutt SL, Heavey B, Rolink AG, and Busslinger M (1999). Commitment to the B-lymphoid lineage depends on the transcription factor Pax5. Nature 401:556-562.

Parfitt AM, Drezner MK, Glorieux FH, Kanis JA, Malluche $\mathrm{H}$, Meunier PJ, Ott SM, and Recker RR (1987). Bone histomorphometry: Standardization of nomenclature, symbols, and units. J Bone Miner Res 2:595-610.

Pennica D, Hayflick JS, Bringman TS, Palladino MA, and Goeddel DV (1985). Cloning and expression in Escherichia coli of the cDNA for murine tumor necrosis factor. Proc Natl Acad Sci USA 82:6060-6064.

Polic B, Hengel H, Krmpotic A, Trgovcic J, Pavic I, Lucin P, Jonjic S, and Koszinowski UH (1998). Hierarchical and redundant lymphocyte subset control precludes cytomegalovirus replication during latent infection. J Exp Med 188:10471054.

Rifas L (1999). Bone and cytokines: Beyond IL-1, IL-6 and TNF- $\alpha$. Calcif Tissue Int 64:1-7.

Shafritz AB, Shore EM, Gannon FH, Zasloff MA, Taub R, Muenke M, and Kaplan FS (1996). Overexpression of an osteogenic morphogen in fibrodysplasia ossificans progressiva. N Engl J Med 335:555-561.

Sharrock WJ (1998). Bone and the hematopoietic and immune systems: A report of the proceedings of a scientific workshop. J Bone Miner Res 13:537-543.
Shimizu T, Mehdi R, Yoshimura Y, Yoshikawa H, Nomura S, Miyazono K, and Takaoka K (1998). Sequential expression of bone morphogenetic protein, tumor necrosis factor, and their receptors in bone-forming reaction after mouse femoral marrow ablation. Bone 23:127-133.

Smitson G, Medina K, Ponting I, and Kincade PW (1995). Estrogen suppresses stromal cell-dependent lymphopoiesis in culture. J Immunol 155:3409-3417.

Suva LJ, Seedor JG, Endo N, Quartuccio HA, Thompson DD, Bab I, and Rodan GA (1993). Pattern of gene expression following rat tibial marrow ablation. J Bone Miner Res 8:379387.

Tanaka H, Barnes J, and Liang CT (1996). Effect of age on the expression of insulin-like growth factor-I, interleukin-6, and transforming growth factor- $\beta$ mRNAs in rat femurs following marrow ablation. Bone 18:473-478.

Urist MR (1995). The first three decades of bone morphogenetic protein research. Osteologie 4:207-223.

Van Snick J, Cayphas S, Szikora JP. Renauld JC, Van Roost E, Boon T, and Simpson RJ (1988). cDNA cloning of murine interleukin-HP1: Homology with human interleukin 6. Eur J Immunol 18:193-197.

Vargas SJ, Naprta A, Lee S-K Kalinowski J, Kawaguchi H, Pilbeam CC, Raisz LG, and Lorenzo JA (1996). Lack of evidence for an increase in interleukin- 6 expression in adult murine bone, bone marrow, and marrow stromal cell cultures after ovariectomy. J Bone Min Res 11:1926-1934.

Vignery A, Silvergate A, Horowitz M, Schultz L, and Baron R (1981). Abnormal remodeling activity in the immunodeficient (nu/nu) and motheaten (me/me) mutant mice. [abstract] Calcif Tissue Int 33:301.

Wozney JM and Rosen V (1998). Bone morphogenetic protein and bone morphogenetic protein gene family in bone formation and repair. Clin Orthop 346:26-37.

Yamazaki H, Kunisada T, Ishuzu A, Ikeda H, Miyoshi I, Sudo $\mathrm{T}$, Hayashi Si, and Yoshiki T (1998). Promotion of early osteoclastogenesis and $\mathrm{B}$ lymphopoiesis in the bone marrow of transgenic rats with the env-pX gene of human T-cell lymphotrophic virus type I. Oncogene 17:2955-2960.

Yasuda H, Shima N, Nakagawa N, Yamaguchi K, Kinosaki M, Mochizuki S, Tomoyasu A, Yano K, Goto M, Murakami A, Tsuda F, Morinaga T, Higashio K, Udagawa N, Takahashi N, and Suda T (1998). Osteoclast differentiation factor is a ligand for osteoprotegerin/osteoclastogenesis-inhibitory factor and is identical to TRANCE/RANKL. Proc Natl Acad Sci USA 95:3597-3602.

Young MF, Ibaraki K, Kerr JM, Lyu MS, and Kozak CA (1994). Murine bone sialoprotein (BSP): cDNA cloning, mRNA expression, and genetic mapping. Mamm Genome 5:108-111. 